\title{
Metamorphosis and estuarine colonisation in the common sole, Solea solea (L.): implications for recruitment regulation
}

\author{
Rachid AMARA $^{a *}$, Françoise LAGARDERE ${ }^{b}$, Yves DESAUNAY ${ }^{c}$, Jocelyne MARCHAND ${ }^{d}$ \\ ${ }^{a}$ Université du Littoral, UPRESS-A ELICO 8013 CNRS, avenue Foch, B.P. 59, 62930 Wimereux, France \\ ${ }^{\mathrm{b}}$ Centre de recherche en écologie marine et aquaculture de l'Houmeau, CNRS-IFREMER, B.P. 5, \\ 17135 L'Houmeau, France \\ ${ }^{\mathrm{c}}$ IFREMER laboratoire d'écologie halieutique, BP 21105, 44311 Nantes, France, cedex 03 \\ ${ }^{\mathrm{d}}$ Laboratoire de biologie marine, faculté des Sciences et Techniques, 2, rue de la Houssinière, \\ 44072 Nantes cedex 03, France
}

Revised 26 October 1999; accepted 6 December 1999

This article is dedicated to the memory of Jocelyne Marchand who worked tirelessly to further our knowledge of the sole.

\begin{abstract}
Processes involved in both metamorphosis and settlement of young sole were studied at the population, cohort and individual level in order to evaluate their role in survival and recruitment regulation. Metamorphosis can be defined as a phase of variable duration (10 days on average) at the end of which the larval period of pelagic dissemination is completed. Size at the onset of metamorphosis is considerably less variable than age and is less plastic to environmental change. Metamorphosis is triggered by the acquisition of a competent size and a sufficient store of energy supplies, and occurs without a nutritional crisis or growth arrest. In addition, changes in organogenesis and behaviour that occur during metamorphosis seem to contribute to horizontal transfer, thus favouring a coastal accumulation. The initiation of estuarine colonization is controlled by the hydrological conditions in the bays and estuaries. In the northern part of the Bay of Biscay, metamorphosis does not seem to be a critical period in the life cycle of the sole. On the contrary, some of our observations suggest that it is a time of convergence, when the variability induced during the planktonic larval phase tends to decrease. It is suggested that metamorphosis initiates the processes which dampen variations of pre-recruitment number. (C) 2000 Ifremer/CNRS/IRD/Éditions scientifiques et médicales Elsevier SAS
\end{abstract}

Solea solea / larva / juvenile / critical phase / estuarine colonisation

Résumé - Métamorphose de la sole Solea solea (L.) et colonisation des nourriceries : implications sur la régulation du recrutement. Les modalités de métamorphose et de colonisation des nourriceries estuariennes ont été étudiées à l'échelle d'un individu, d'une cohorte et de la population. La métamorphose se définit comme une phase de durée variable (10 jours en moyenne) au terme de laquelle s'achève la dissémination larvaire. La taille au début de la métamorphose est beaucoup moins variable que l'âge : leurs coefficients de variation respectifs sont 0,08 et 0,2 . La métamorphose se déclenche avec l'acquisition d'une taille et d'un stockage énergétique suffisants et elle se déroule sans crise nutritionnelle ni arrêt de croissance. Les changements morpho-anatomiques (p. ex. l'inflation de la vessie gazeuse) et comportementaux qui l'accompagnent semblent contribuer au transfert horizontal des juvéniles et, en fin de métamorphose, favoriser leur pénétration en zone côtière et la colonisation des estuaires. Ce dernier processus est contrôlé par la structure hydrologique de l'estuaire, laquelle dépend du débit fluvial, du cycle de marée et du régime des vents. La colonisation peut être concentrée sur une seule

\footnotetext{
*Correspondence and reprints: ramara@loalit.univ-littoral.fr
} 
période (avril) ou étalée d'avril à juin. Dans le golfe de Gascogne, la métamorphose ne semble pas être une phase critique du cycle de vie de la sole. Au contraire, nos observations amènent à la considérer comme un moment de «convergence» où la variabilité induite durant la période larvaire tend à s'atténuer; il en résulte probablement un même potentiel de survie pour les larves issues de différentes cohortes durant et au terme de la métamorphose et une régulation du nombre de pré-recrues. Les juvéniles sont concentrés exclusivement dans les nourriceries côtières et estuariennes bien que d'importantes densités et biomasses de proies méiobenthiques soient disponibles sur tout le plateau continental. Cependant, dans les nourriceries, caractérisées par des surfaces habitables limitées, la concentration des prédateurs potentiels, la variabilité des conditions hydroclimatiques, les risques de mortalité des jeunes soles sont encore mal évalués. (C) 2000 Ifremer/CNRS/IRD/Éditions scientifiques et médicales Elsevier SAS

\section{Solea solea / larve / juvénile / phase critique / colonisation estuarienne}

\section{INTRODUCTION}

The metamorphosis of fish is a process which is initiated by ontogenetic transformations and ends when fish acquire the form and the behaviour of juveniles [68]. The planktonic larval stages last for about one to three months in the majority of flatfish species $[15,36,51,60]$, although in certain species they can last much longer. For example, in the pleuronectid Microstomus pacificus they can last between nine months and two years [12]. In flatfish, metamorphosis is characterized by very clear morphological (e.g. eye migration and a $90^{\circ}$ rotation in posture), anatomical and physiological transformations which give rise to new types of behaviour and induce the transition from a pelagic to a benthic lifestyle.

Metamorphosis is a stage which requires a lot of energy [7]. In a certain number of species it corresponds to a period of nutritional crisis [43, 61], strong metabolic changes together with the slowing down of metabolic activity [68], and a re-calibration of vision in order to detect prey [53]. All of these phenomena can increase the vulnerability of the larvae. In addition, the transition to new habitats exposes the young fish to new forms of competition and predation [29]. Toward the end of metamorphosis, young sole colonize unstable nursery ecosystems situated in bays and estuaries $[48,22]$. This stage may be crucial to the survival of the new settlers due to the variable hydrological conditions in the nurseries, but also to predation and competition for space and resources [66]. This is why an increasing number of authors believe that the year class strength of many fish species is generally determined either during or just after meta- morphosis $[8,36,55,69]$. In other words, the success of the year class could depend on the success or failure during this phase. Despite these considerations, very few studies have assessed in an ecological context the importance of the processes involved in the transition to a benthic life for the control and / or regulation of recruitment $[15,50]$ (controlling factors or processes are defined as those that generate the among-year variability in year-class whereas regulating factors or processes reduce this among-year variability). This is surprising, given the importance of these processes particularly when the time-space window in which the larvae metamorphose is relatively large, as is the case for sole in the Bay of Biscay [1].

This review is based mainly on results that have already been published. Our intention is to clarify the importance of two aspects of the life cycle, metamorphosis and nursery colonisation, in determining sole recruitment in the Bay of Biscay. The approach adopted in this study is to explain the potential links between how these events happen and their immediate or subsequent consequences on the fate of young sole. The results presented here are based on a series of sampling cruises in the northern part of the Bay of Biscay in 1992 and 1993 between a depth of $100 \mathrm{~m}$ and the mouth of the Vilaine estuary, and on a follow-up study of this estuary over several years (figure 1). The sampling procedures used during these cruises are described in detail in Amara et al. [4], Marchand and Masson [48] and Amara and Bodin [2]. For convenience, we have used a scale of stages (4 and 5) and sub-stages (4b, 5a and 5b) to describe the main phases of metamorphosis [41]. The most obvious sign that metamorphosis has begun is the initiation of ocular migration, which is classified under 
sub-stage $4 \mathrm{~b}$. The final phase of metamorphosis takes place at sub-stage $5 \mathrm{~b}$. Our objectives were therefore (i) to describe metamorphic traits and to place the key stages of metamorphosis in the ecological context of the distribution of larvae and their prey, (ii) to analyse the nutritional condition of larvae during this phase, and (iii) to examine the processes involved in the estuarine colonisation.

\section{THE ONTOGENETIC AND ECOLOGICAL CONTEXT}

\subsection{Size and age at the onset of metamorphosis}

The 1992 and 1993 cruises provided us with the possibility to study the magnitude of the seasonal and

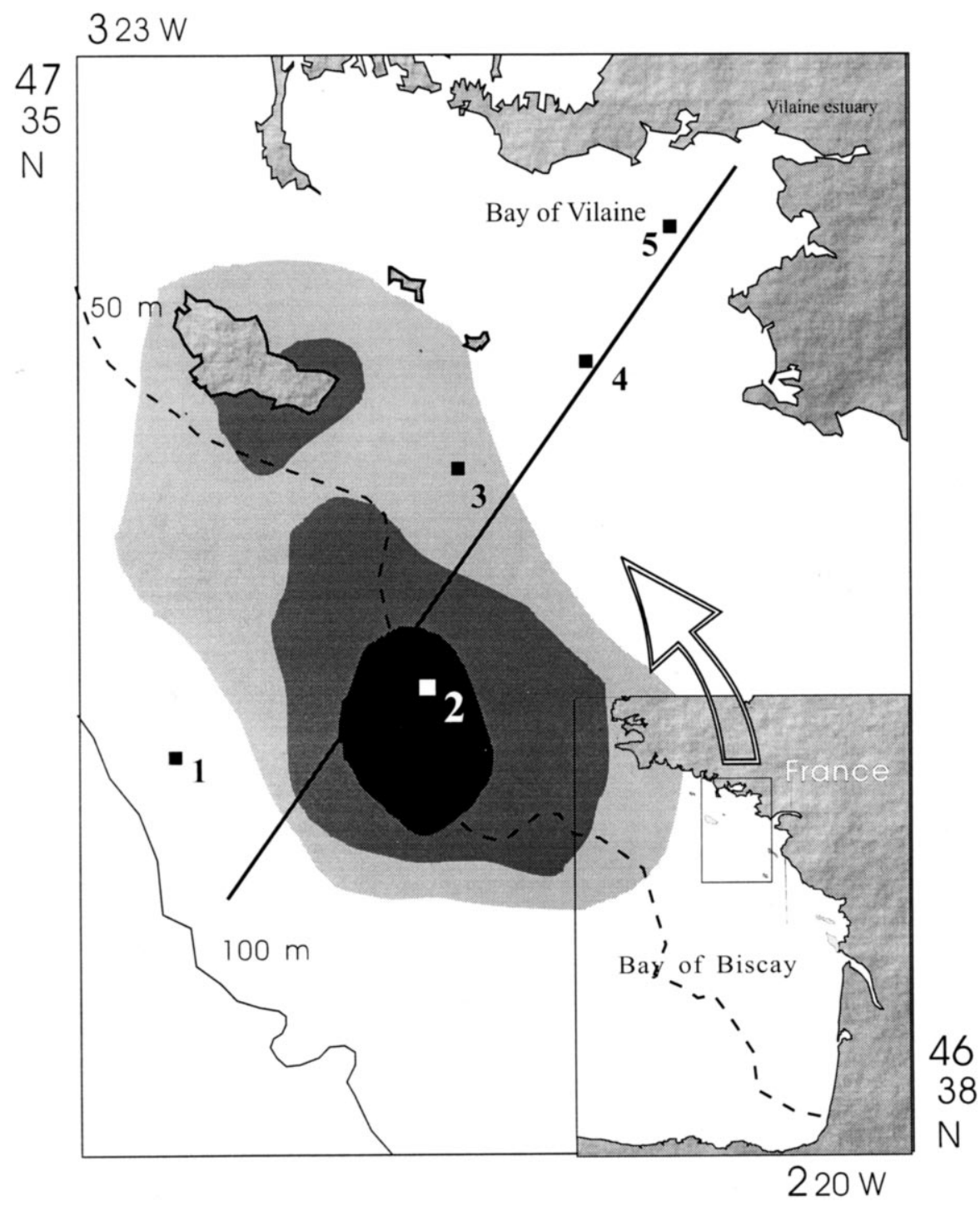

Figure 1. Map of the studied area, showing the onshore-offshore transect surveyed during cruises by using the 'Zébulon' and the location of the station sampled for analyses of the meiofauna. The main sole spawning grounds are indicated according to Koutsikopoulos et al. [38] (sole egg densities number per $100 \mathrm{~m}^{3}: \mathbf{0}>10$; 5-10; $\square 1-5$ ). 


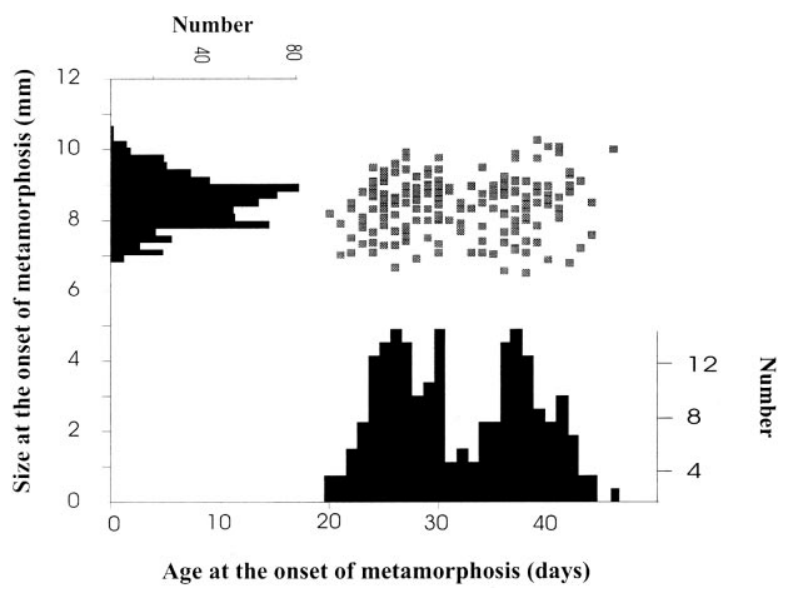

Figure 2. Size and age (in days) at the onset of metamorphosis (stage 4b) of sole larvae caught in 1992. Each point on the bivariate plot represents the length and age of an individual $(\mathrm{n}=$ 171). N: number of larvae. Size histogram $(n=472)$; age histogram $(\mathrm{n}=185)$ (modified from [3]).

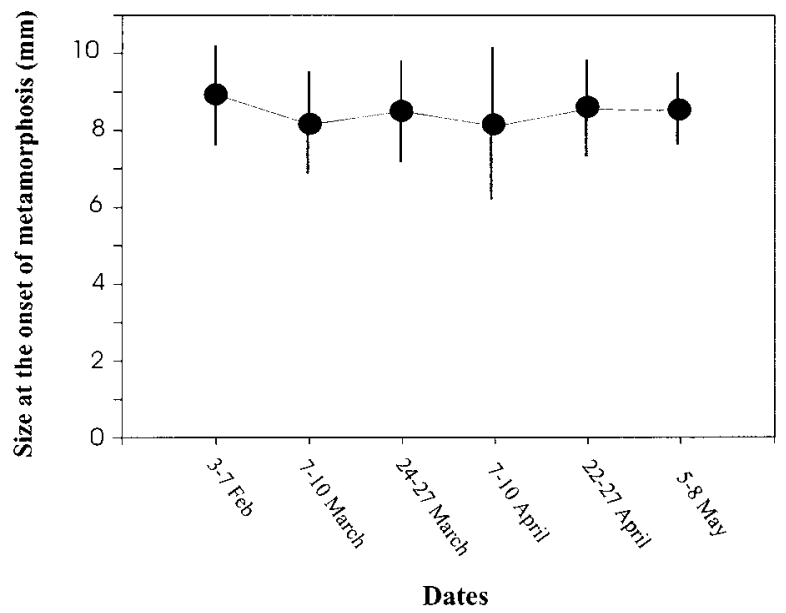

Figure 3. Seasonal changes in the mean larval size ( 2 standard deviations) at the onset of metamorphosis $(\mathrm{n}=402)$.

yearly variations in size and age at the onset of metamorphosis. The transect sampling also had the advantage of identifying possible gradients from the coast to the open sea [3]. The age of larvae at the onset of metamorphosis, as estimated from otolith microstructure analysis, varies between 20 and 46 days (not including the embryonic period) and their size (standard length Ls) varies between 6.9 and 10.4 $\mathrm{mm}$ (figure 2). There is no significant correlation between size and age at the onset of metamorphosis $\left(\mathrm{r}^{2}=0.02\right)$. Sole larvae begin to metamorphose at the relatively constant size of $8.5 \mathrm{~mm} \times 1.3 \mathrm{~mm}$ and seasonal, yearly and spatial comparisons show that this size does not vary significantly (figures 3, 4). In contrast to this, there are large seasonal and yearly variations in the age at which metamorphosis starts (e.g. 41 days in February compared with 25 days in May 1992) (figure 5). This depends on differences in the growth rate, which in turn are correlated with temperature changes and food availability [3]. It is worth noting that in 1993 there were no seasonal variations in the age of larvae at the onset of metamorphosis (figure 5). This is probably due to the fact that in 1993 temperatures were relatively stable during the period when the larvae were present, compared to the same period in 1992. According to Fage [24], duration and size are "specific constants" that are modulated by "the subtleties of life's phenomena". Size at the onset of metamorphosis is considerably less variable than age for the Bay of Biscay sole: the coefficient of variation for size is 0.08 , compared with 0.2 for age. Similar results were obtained with sole from the western part of the Channel and from the southern part of the North Sea (Amara, unpublished data). These results are in agreement with those on the age and size at metamorphosis of other flatfish species reared in hatcheries [14, 36, 56]. This phenomenon has also been demonstrated with coral reef fish $[20,49,65]$. The metamorphosis of the sole seems then to be conditioned by the acquisition of a competent size. Is this a sufficient reason to conclude that size is the determining factor for the initiation of metamorphosis as has been suggested by Policansky [56] for the Pacific plaice Platichthys stellatus and Victor [65] for the labrid Thalassoma bifasciatum? Generally speaking, a change in habitat is often more closely related to size than to age [27]. Furthermore, for a given species, ontogenetic changes are more closely related to size than to the age of the fish [16, 26]. Fish metamorphosis is a complex process involving endocrinal systems whose stimulation is under the control of climatic (temperature) and non climatic (photoperiod) factors [33, 68]. The initiation of metamorphosis in the Pleuronectidae is often associated with an increase in the secretion of thyroid hormones [35], and this has also been observed in the sole [54]. Like Chambers and Leggett [14], we view size as a character that describes an individual at metamorphosis rather than invoking a dependency of metamorphosis on that character. 




Distance to the coast $(\mathbf{k m})$

Figure 4. Sizes of sole larvae at the onset of metamorphosis $(n=402)$ along the surveyed onshore-offshore transect (modified from [3]).

(a)

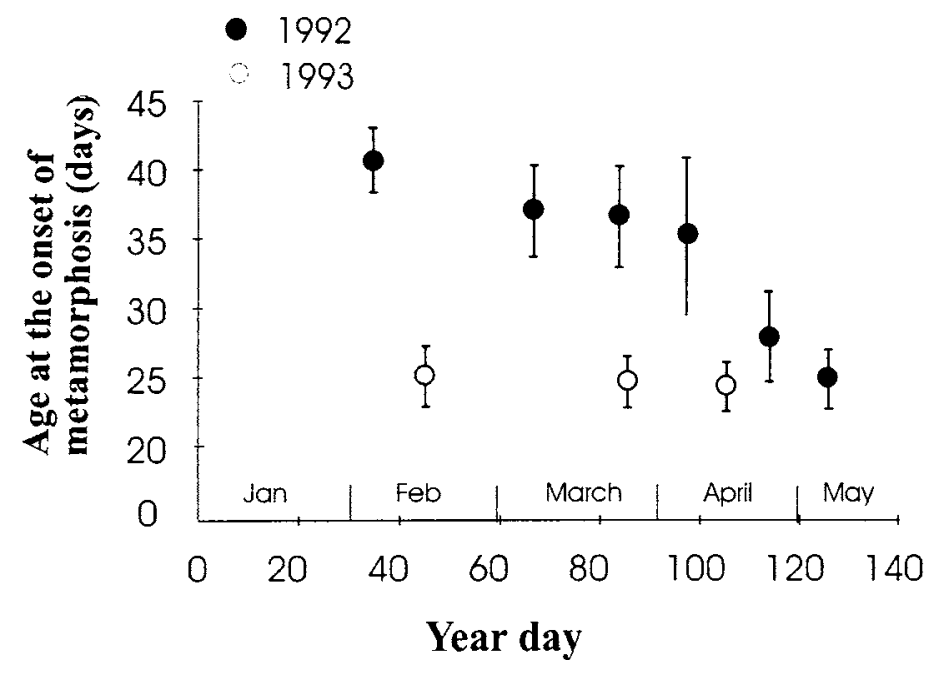

(b)

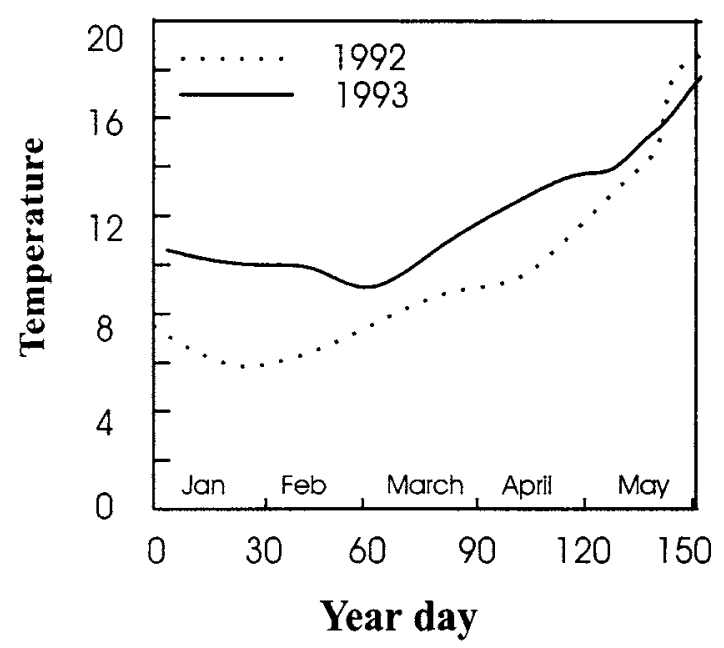

Figure 5. Seasonal change in (a) mean ages (2 standard deviations) of larvae at the onset of metamorphosis in 1992 and 1993 and (b) water temperature recorded at $4 \mathrm{~m}$ below the surface.

\subsection{Modifications in vertical and horizontal distribution}

A series of sole larvae samples was taken over a 28-hour period in April 1991 from a fixed station located in the outermost part of Vilaine bay (at a depth of $40 \mathrm{~m}$ ), using alternately a supra-benthic sampler, (the 'Zébulon' [21]) and a plankton net. Comparing the captures of the Zébulon with those using plankton nets confirmed that the bottom 


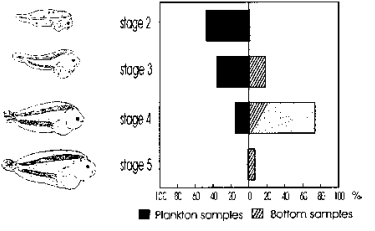

Figure 6. Percentage (combined-24 h catches) of sole larvae of different developmental stages in the plankton and bottom samples taken at a fixed station.

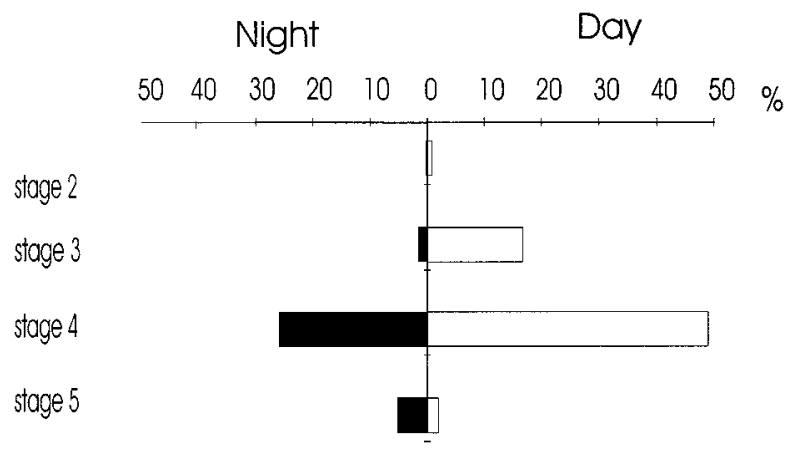

Figure 7. Percentage of sole larvae of different developmental stages obtained from bottom day/night samples.

sampler picks up mainly the late larval stages. The latter are poorly represented in the water column, a situation which is exactly the opposite for the first stages of development (figure 6). The distribution of captures near the sea-bed shows that larvae are more abundant during the day (figure 7). This can be explained by the fact that as early as the first feeding stages (stage 2), sole larvae migrate toward the surface at night and are concentrated in the bottom layers during the day [38]. This nycthemeral vertical larval migration was observed with the same species reared in tank experiments [18].

During development, many fish move actively and/or passively from spawning areas to coastal nurseries. In the northern Bay of Biscay, sole spawning grounds are offshore in typically marine waters, whereas nurseries are in coastal and estuarine areas. According to Koutsikopoulos et al. [38] diffusion could be responsible for most of the transport of larvae to the coast. However, recent field and experimental studies indicate that vertical migration of metamorphosing larvae and newly settled juveniles are involved in the migration from offshore spawning areas to coastal nurseries [17, 19, 42]. For species that have an estuar- ine phase in their life cycle, larval and young juvenile behaviour is often synchronised with the tides (selective tidal transport) $[11,58]$. Comparisons made with the thickback sole (Microchirus variegatus), a species which never leaves the continental shelf and whose entire life cycle is completed without it ever entering the littoral zone, show that the characteristics that differentiate this species from the sole $(S$. solea) appear during the late larval stages [6]. These include vertical distribution, the extent of nycthemeral migration and the presence or absence of a swimbladder. The swimbladder of $S$. solea is inflated at the beginning of metamorphosis [9] whereas it is absent in $M$. variegatus. The swimbladder functions during the behavioural development of larvae are poorly understood. In addition to its hydrostatic function, the swimbladder could play a role in recording hydrostatic pressure variations linked to the tide [30]. Indeed the inflation of the sole's swimbladder during metamorphosis coincides with an increased sensitivity to pressure variations of tidal amplitude [45]. This supports the hypothesis put forward by F. Lagardère [39] that metamorphosing larvae could be transported toward the coast by the selective use of tidal currents, and in this way colonise the nurseries.

As for horizontal distribution, the majority of larvae that begin to metamorphose (stage $4 \mathrm{~b}$ ) are found on the continental shelf between 20 and $90 \mathrm{~km}$ offshore (figure 8). Nevertheless, after this stage very few metamorphosing larvae (stages $5 \mathrm{a}$ and $5 \mathrm{~b}$ ) are captured around the spawning ground; most captures are made near the stations that are closest to the coast [4 and 42]. This distribution pattern is also true for other species of flatfish [36].

\subsection{Meiobenthic resources beyond the coastal nurseries}

The fact that the majority of larvae begin to metamorphose on the continental shelf implies either that there is a transfer of larvae to the coast during metamorphosis, or that some larvae settle offshore or perhaps even near the spawning ground. However, none of the newly settled sole have ever been captured beyond the coastal nurseries [4, 37], in contrast to the young benthic stages of the other species of Soleidae, Microchirus variegatus [6]. This begs the question as to what happens to sole that settle on the 
bottom before they can reach the coast. In his transport hypothesis, Hjort [32] suggests that metamorphosing larvae that are transported to depths inappropriate for settlement are lost to the population. According to Gibson [29], the availability of food and predation are the two most important factors which determine the quality of the juvenile flatfish habitat.

In 1993, we studied the meiobenthic trophic environment at five stations where sole larvae were likely to settle, lying between a depth of $100 \mathrm{~m}$ and the mouth of the Vilaine estuary (figure 1). These stations have a high density and biomass of potential meiobenthic prey for young sole. Near the spawning ground where

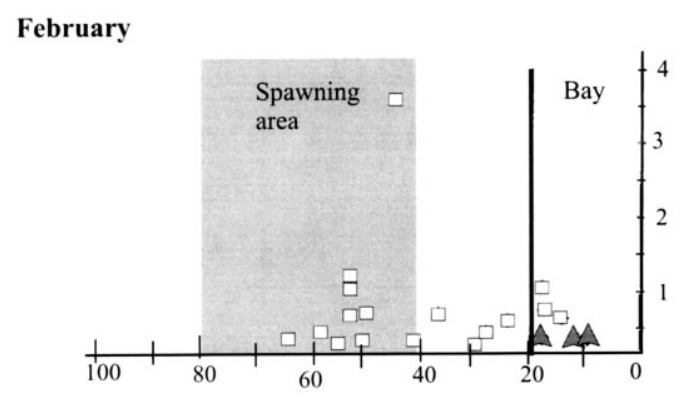

March


Figure 8. Density of metamorphosing larvae along the onshoreoffshore transect. $\square$ stage $4 \mathrm{~b}$ (onset of metamorphosis); $\boldsymbol{\Delta}$ stage $5 \mathrm{a}$; stage $5 \mathrm{~b}$. the majority of larvae begin to metamorphose [4], the harpacticoid copepods, which are the preferred prey of young benthic sole [2, 13, 48], are various and abundant (figures 9, 10). These results suggest that the fate of larvae which settle before reaching the coastal nurseries is probably not determined by the quality and the quantity of benthic food available at these depths.

\section{NUTRITIONAL CONDITION OF METAMORPHOSING LARVAE}

\subsection{Nutrition and feeding rate}

The feeding activity and vertical distribution of larvae are important for our understanding of the mechanisms which lead to the colonisation of coastal nurseries. For this reason, we carried out two 24-hour sampling cycles in 1993 in the outermost part of Vilaine bay [42].

An analysis of the gut contents (stages $4 \mathrm{~b}$ and $5 \mathrm{a}$ ) show that metamorphosing larvae ingest mainly planktonic prey (around 80\%) (mainly copepods, cladocerans and nauplii) although some epibenthic prey (polychaetes fragments, harpacticoid copepods, small bivalves and gastropods, and very few amphipods) began to contribute to larval diet. The quantity of food ingested during each sampling cycle was analysed in terms of carbon and nitrogen content [42]. The quantity of carbon and nitrogen begins to decrease at the end of the day and is lowest at dawn, after which it starts to increase again (figure 11). This indicates that larvae undergoing metamorphosis have not modified their previous feeding habits, since they continue to feed on plankton during the day and digest their prey at night. In the nurseries, sole at the end of metamorphosis (stage 5b) that are in the process of settling on the bottom continue to migrate up the water column at night. At this stage they feed on the epibenthic meiofauna (mainly harpacticoid copepods) then, with increasing age, they begin to consume the endobenthic prey that live in the top layers of the sediment $[47,2]$. These results suggest that the vertical migrations observed in larvae undergoing metamorphosis or in young sole in the estuary 


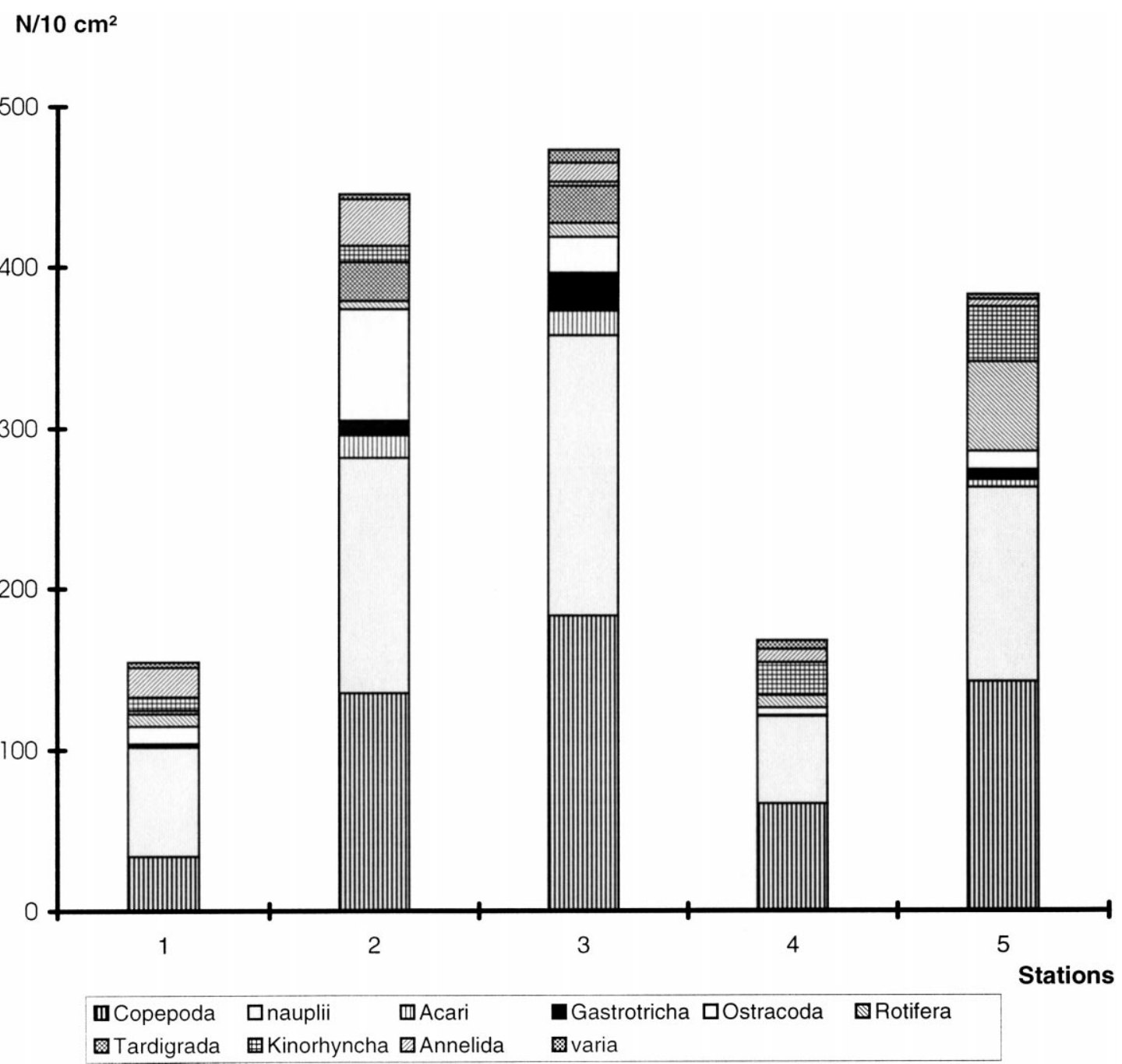

Figure 9. Density of meiofauna at each station sampled on the shelf in April 1993 (from [2]).

is not related, at least directly, to their feeding activity.

\subsection{Nutritional condition}

Numerous studies have underlined the importance of the mortality that occurs during or just after metamorphosis $[8,36,62]$ but very few have looked at the nutritional status (or condition) of larvae during this phase $[10,50]$. The passage to a new kind of habitat exposes the young fish to new sources of competition (intra- and inter-species) and predation. As a result, the condition of the fish at the beginning of metamorphosis may determine their survival. Using the ratio of the quantity of triacylglycerol (high energy lipid reserves) to that of sterol (structural lipids ) (TAG/ ST) $[28,31]$, which is a nutritional condition index that is very sensitive to starvation, we tested the hypothesis that from a metabolic point of view metamorphosis corresponds to a critical phase.

The change in the average triacylglycerol contents during ontogenic development (figure 12) shows that larvae accumulate triacylglycerol and reach metamorphosis with probably enough energy reserves to cover 
the extra energy requirements of this phase. Ehrlich [23] also found this with plaice. The nutritional condition of larvae at the onset of metamorphosis shows significant seasonal differences $\left(\mathrm{F}_{3,81}=15.9 ; P<\right.$ 0.001 ), but no clear pattern emerges (figure 13). Nevertheless, in each of the cruises the average TAG/ ST ratio of larvae at the onset of metamorphosis was always greater than 1 , the experimental value below which undernutrition is manifest in sole larvae [28]. There are yearly differences in the nutritional condition: in 1993 a much higher percentage of larvae (39\%) were in a poor nutritional condition (TAG/ST <1) compared with $1992(15 \%)$.

The individual TAG/ST values of larvae at the onset of metamorphosis as a function of the distance from the coast where they were captured is shown on 14 . There is a wide distribution of values, with large variations at a single station. However, the nutritional condition of the larvae does not tend to improve along a gradient running from the open sea to the coast. Whatever the distance from the coast, the majority of larvae have a satisfactory nutritional condition $(\mathrm{TAG} / \mathrm{ST}>1)$.

Thus from a nutritional point of view metamorphosis cannot be considered to be a critical phase for the
Bay of Biscay sole. Indeed, there is no trophic crisis during this phase: the gut fullness index calculated during the two 24-hour observation cycles in 1993 show that only $16 \%$ and $36 \%$ of metamorphosing larvae examined had empty guts [42]. It has been shown that sole larvae are highly resistant to starvation during this developmental stage [57]. Moreover, growth is continuous during this phase; the total length (Lt) of larvae grew from $9 \mathrm{~mm}$ at stage $4 \mathrm{~b}$ (onset of metamorphosis) [3] to $10 \mathrm{~mm}$ when they entered the Bay of Vilaine, mainly at stage 5a, and to $12 \mathrm{~mm}$ when they settled in the estuary at stage $5 \mathrm{~b}$ (end of metamorphosis) [46].

Triacylglycerols are used for energy requirements and are thus a direct measure of a larva's potential for withstanding periods of starvation [31]. If one accepts that the vulnerability of larvae to predation depends mainly on their nutritional condition [25, 44], the lipid indexes based on triacylglycerol contents may be considered to be a measure of the probability of short and medium term survival. Based on this, our results suggest that during any given year, larvae from different cohorts probably have the same chance of survival during or just after metamorphosis.

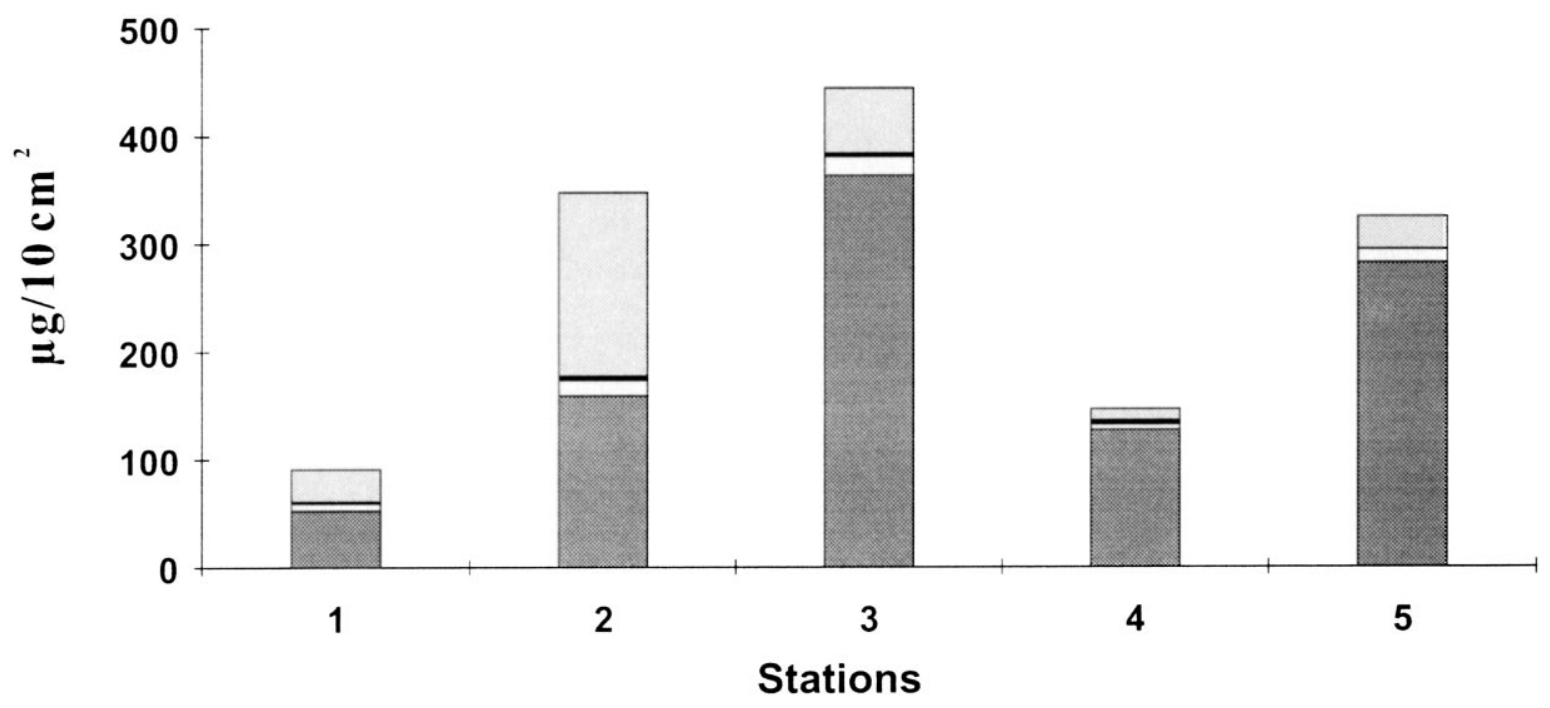

copepoda $\square$ nauplii $\square$ Bivalvia $\square$ ostracoda

Figure 10. Biomass of potential sole prey at each meiofauna station in April 1993 (from [2]). 

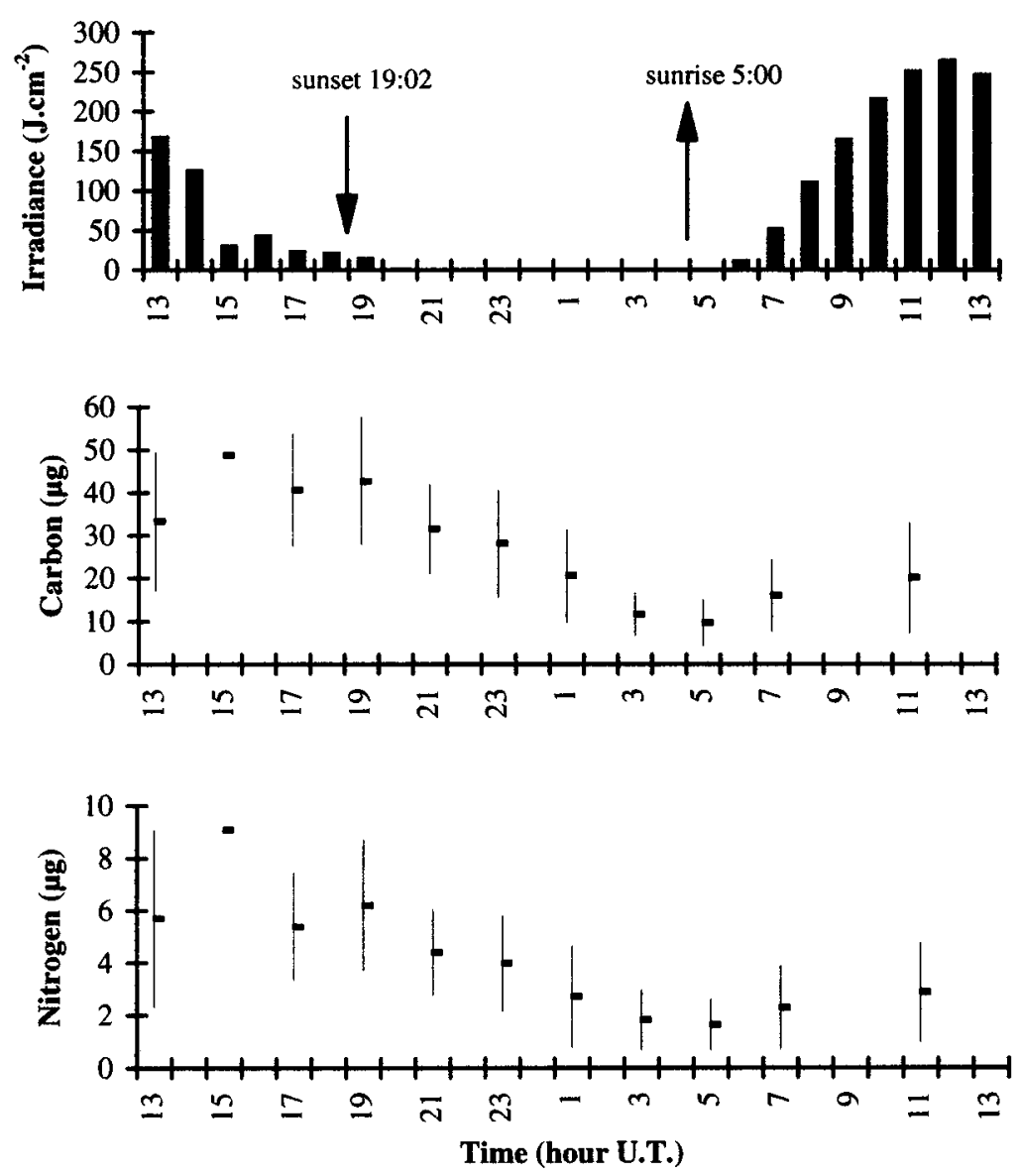

Figure 11. Hourly variations in the mean carbon and nitrogen content (1 standard deviation) in the gut contents of metamorphosing sole caught in late April 1993, as a function of daytime illumination (arrows give hours of sunset and sunrise, respectively) (data from [42]).

\section{COLONISATION OF COASTAL NURSERIES: THE CASE OF THE VILAINE ESTUARY}

Surveys were carried out from 1986 to $1990[48,47]$ and in 1992 [5] in the Vilaine estuary. These studies showed that young sole enter the estuary at the end of metamorphosis, mainly at stages $5 \mathrm{a}$ and $5 \mathrm{~b}$ and as newly settled sole. Estuarine colonization takes place between the beginning of April and the month of June, with an influx to the nursery that may be concentrated in a single period (April) or be spread out from April to June [48]. In April, colonization always begins with an accumulation of young sole at the entrance of the estuary (figure 15).

For plaice, Hovenkamp [34] showed that the period of larval arrival near the nursery areas and subsequent immigration and settlement is potentially criti-

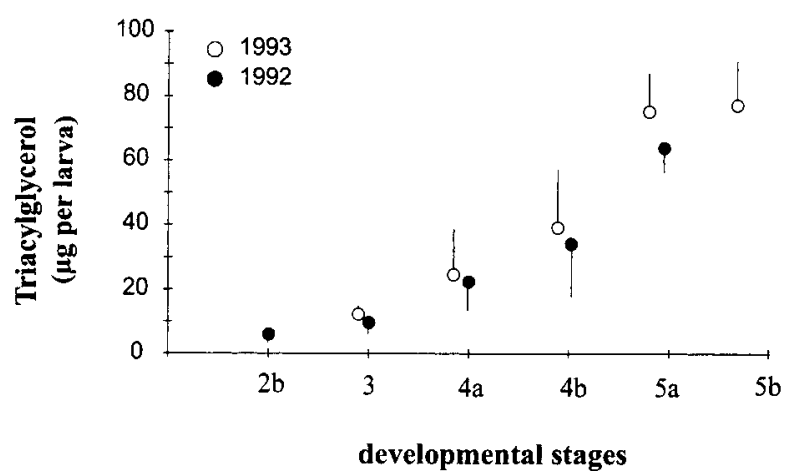

Figure 12. Mean and standard deviation of triacylglycerols contents (1 standard deviation) during sole larva ontogenesis $(\mathrm{n}=$ 125). 


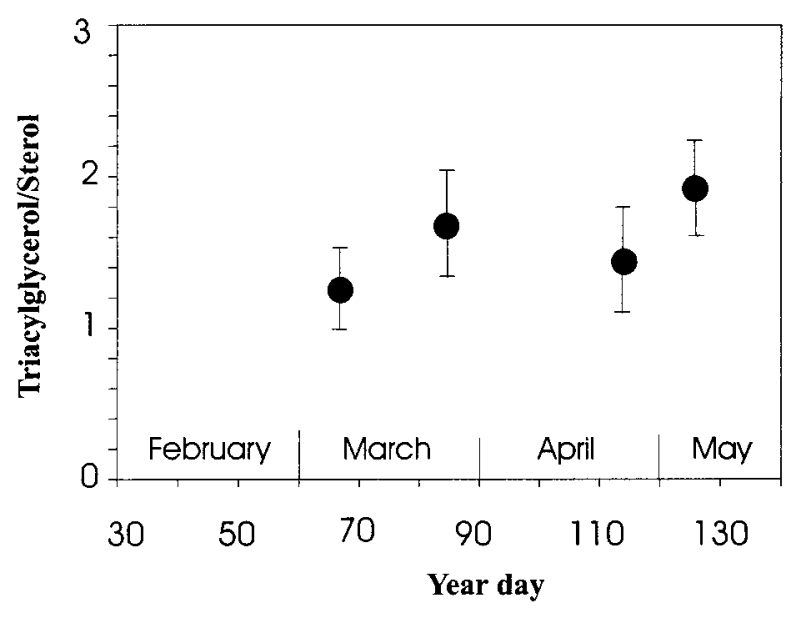

Figure 13. Seasonal variations in the mean triacylglycerols / sterol ratio (1 standard deviation) of larvae at the onset of metamorphosis in $1992(\mathrm{n}=81)$.

cal. In the Bay of Vilaine, the time of initiation of sole estuarine colonization can vary enormously, depending on the balance between sea water and river water, which is regulated by a combination of the direction and intensity of the winds, the river flow and the tidal cycle. A combination of a strong river flow and offshore wind is unfavourable to the estuar- ine penetration. In this case, the young sole can wait in the bay, which acts as a 'transit zone'. Conversely, when the river flow is low, the wind influence is less obvious and whatever its orientation, marine waters enter the estuarine area (mainly by the bottom) favouring estuarine penetration. A comparison of the vertical distribution of metamorphosing sole and their potential predators (e.g. Pleurobrachia pileus (Ctenophora) and Aurelia aurita (Cnidaria)) at the time when the estuary is being colonized shows that the risk of mortality from predation is low due to the difference in their spatial and temporal distributions. Moreover, an analysis of the digestive contents of the predators did not provide any evidence that sole had been ingested [48].

The factors which determine nursery colonization are poorly understood. The role of attractants (mainly glycine-betain) in the sediment and in food has been mentioned [47]. Experiments have shown that the behaviour of metamorphosing larvae and sole juveniles may be determined by numerous factors such as light, gravity, substrate, food, salinity, pressure and currents [18]. The combined action of the currents and rheotaxis on the one hand and light and pressure on the other, probably initiates an active migration

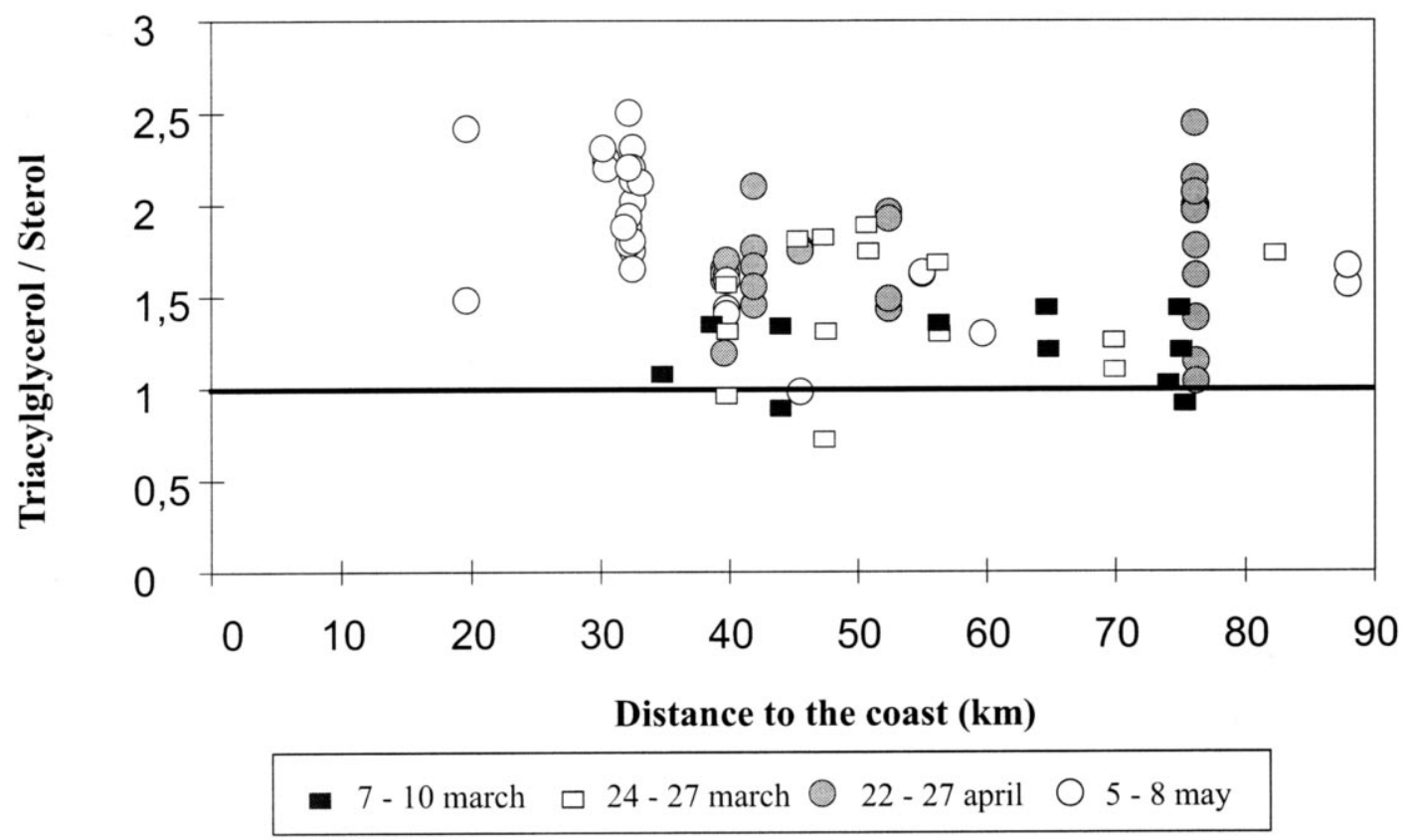

Figure 14. Triacylglycerols / sterol ratio of larvae at the onset of metamorphosis sampled along the onshore-offshore transect in 1992 $(\mathrm{n}=81)$. 



Distance from Arzal dam $(\mathrm{km})$

$-1987-1988 \ldots 1989---1990$

Figure 15. Yearly comparisons of the spatial distribution of juvenile sole in the Vilaine ecosystem from April to June (modified from [47]). 
that allows the young sole to enter the estuary and to settle there [19].

Whatever the processes that determine their entry into the estuary, the estuarine system would appear to be an obligatory step in the life cycle of the sole in the studied area. This might be related to the wealth of potential prey available throughout the submerged and intertidal zones which covers a larger surface in an estuary. The young benthic stages feed there as soon as the tidal conditions make it accessible [40] and the high temperatures found in this zone are favourable to growth. From the comparison of the sole with other species whose young remain in the bay, such as the dab Limanda limanda or the solenette Buglossidium luteum, it would appear that there is a tropism towards low salinity zones, implying a specific degree of dependency on the estuary.

\section{CONCLUSION}

In the northern part of the Bay of Biscay, the metamorphosis of the sole is a particularly well adapted process which ends the pelagic dissemination phase and occurs without a nutritional crisis or growth arrest. Moreover, some of our observations suggest that this period is one of 'convergence', when the variability induced during the larval phase tends to fade. During the period just after metamorphosis, when the risk of predation depends on size [64, 67] or nutritional condition [44], the fact that individuals from different cohorts are of a relatively similar size and have stored sufficient energy supplies (triacylglycerol) means that they all have the same probability of survival when they enter the benthic environment. Indeed, metamorphosis seems to contribute to the horizontal transfer of larvae, which favours entry into the coastal zone and colonization of the estuary. The risk of having an insufficient quantity of food during this phase or just after settlement is slight. The risk of predation by Ctenophora and Cnidaria, which are sometimes abundant in the coastal zone, is in fact low during the period when the estuary is being colonised, due to differences in spatial and temporal distribution patterns.

These conclusions run counter to the generally held idea that the slowdown in feeding and growth during flatfish metamorphosis leads to a higher mortality.
Must we conclude that in terms of what determines the recruitment of soles, metamorphosis initiates the processes which dampen variations in the number of pre-recruits that occupy the nursery, resulting in a relatively invariable recruitment [59]. Metamorphosis does not actually fulfil the criteria normally attributed to a critical phase. However, the fate of newly settled juveniles in the nursery is probably rather more uncertain. This would suggest that the year class is determined either before metamorphosis or during the juvenile period. According to Myers and Cadigan [52], this is the case for demersal fish populations in which the variability in year class strength has its origin in the larval phase or right at the beginning of the juvenile period. The mortality which then occurs during the juvenile period, provoked by the limited space in the nurseries, only serves to reduce the fluctuations. This has also been suggested by Rijnsdorp et al. [59] and Van der Veer [63] for North Sea sole and plaice respectively.

The study of the control and regulation processes that may take place during the juvenile period will constitute the next stage of this research, and should explain the relative stability of sole recruitment in the Bay of Biscay.

\section{Acknowledgements}

This study was part of the PNDR-Sole programme. The authors thank numerous collaborators from the Ifremer ECOHAL laboratory (C. Koutsikopoulos, D. Dorel, P. Bourriau, P. Beillois, D. Guérault, P. Grellier), from the CREMA L'Houmeau (R. Galois, L. Joassard, K. Dalet) and the Science faculty of the Bretagne Occidentale university (P. Bodin) for their help in the field and the laboratory analyses. They also thank the teams of the oceanographic boats Gwen-Drez and Thalassa for their help during the numerous expeditions.

\section{REFERENCES}

[1] Amara R., La sole, Solea solea (L.), du golfe de Gascogne : métamorphose, transfert des larves vers la côte et colonisation des nourriceries, thèse Univ. Paris 6, 1995, 250 p.

[2] Amara R., Bodin P., L'environnement trophique méiobenthique en dehors des nourriceries côtières est-il favorable à l'installation des jeunes soles?, Oceanol. Acta 18 (1995) 583590. 
[3] Amara R., Lagardère F., Taille et âge au début de la métamorphose chez la sole, Solea solea (L.) du golfe de Gascogne, ICES J. Mar. Sci. 52 (1995) 247-256.

[4] Amara R., Lagardère F., Désaunay Y., Seasonal distribution and duration of the planctonic stage of Dover sole, Solea solea (L). larvae in the bay of Biscay: an hypothesis, J. Fish. Biol. 43 (1993) 17-30.

[5] Amara R., Désaunay Y., Lagardère F., Seasonal variation in growth of larval sole, Solea solea (L.) and consequences on the success of larval immigration, Neth. J. Sea Res. 32 (1994) 287-298.

[6] Amara R., Poulard J.C., Lagardère F., Désaunay Y., Comparison between the life cycles of two Soleidae, the common sole, Solea solea, and the thickback sole, Microchirus variegatus, in the Bay of Biscay, France, Environ. Biol. Fish. 53 (1998) 193-209.

[7] Balon E.K., Types of feeding in the ontogeny of fishes and the life-history model, Environ. Biol. Fish. 16 (1986) 11-24.

[8] Beverton R.J.H., Iles T.C., Mortality rates of 0-group plaice (Pleuronectes platessa L.), dab (Limanda limanda L.) and turbot (Scophthalmus maximus L.) in European waters. II: Comparison of mortality rates and construction of life table for 0-group plaice, Neth. J. Sea Res. 29 (1992) 49-59.

[9] Boulhic M., Gabaudan J., Histological study of the organogenesis of the digestive system and swimbladder of the Dover sole, Solea solea (Linnaeus 1758), Aquaculture 102 (1992) 373-396.

[10] Boulhic M., Galois R., Koutsikopoulos C., Lagardère F., Person-Le Ruyet J., Etat nutritionnel, croissance et survie des stades pélagiques de la sole, Solea solea (L.), du Golfe de Gascogne, Ann. Inst. Océanogr. Paris 68 (1992) 1-22.

[11] Bos A., Tidal transport of flounder larvae in the Elbe river, Germany, Arch. Fish. Mar. Sci. 47 (1999) 47-60.

[12] Butler J.L., Dahlin K.A., Moser H.G., Growth and duration of the planktonic phase and stage based population matrix of dover sole, Microstomus pacificus, Bull. Mar. Sci. 58 (1996) $29-43$.

[13] Castel J., Lasserre P., Régulation biologique du méiobenthos d'un écosystème lagunaire par un alevinage expérimental en soles (Solea vulgaris), Oceanol. Acta $\mathrm{N}^{\circ}$ sp. (1982) 243-251.

[14] Chambers R.C., Leggett W.C., Size and age at metamorphosis in marine fishes: an analysis of laboratory-reared winter flounder (Pseudopleuronectes americanus) with a review of variation in other species, Can. J. Fish. Aquat. Sci. 44 (1987) 1936-1947.

[15] Chambers R.C., Leggett W.C., Possible causes and consequences of variation in age and size at metamorphosis in flatfishes (Pleuronectiformes): an analysis at the individual, population, and species levels, Neth. J. Sea Res. 29 (1992) $7-24$.

[16] Chambers R.C., Leggett W.C., Brown J.A., Variation in and among early life history traits of laboratory-reared winter flounder (Pseudopleuronectes americanus), Mar. Ecol. Prog. Ser. 47 (1988) 1-15.
[17] Champalbert G., Koutsikopoulos C., Behaviour, transport and recruitment of Bay of Biscay sole (Solea solea): laboratory and field studies, J. Mar. Biol. Ass. UK 75 (1995) 93-108.

[18] Champalbert G., Macquart-Moulin C., Patriti G., Étude expérimentale du comportement des larves et des juvéniles de sole, Solea solea (L.), Ann. Inst. Océanogr. Paris 68 (1992) 89-105.

[19] Champalbert G., Marchand J., Le Campion J., Rheotaxis in juvenile sole Solea solea (L.): influence of salinity and light conditions, Neth. J. Sea Res. 32 (1994) 309-319.

[20] Cowen R.K., Variation in the planktonic larval duration of the temperate wrasse (Semicossyphus pulcher), Mar. Ecol. Prog. Ser. 69 (1991) 9-15.

[21] Désaunay Y., Koutsikopoulos C., Porche P., Biellois P., Zébulon a simple suprabenthic gear for ichthyoplancton studies over the continental shelf, ICES CM 1991/L:52, 1991, 1 p.

[22] Désaunay Y., Perodou J.B., Beillois P., Étude des nurseries de poissons du littoral de la Loire-Atlantique, Sci. pêche, Bull. Inst. Pêches Maritimes 319 (1981) 1-23.

[23] Erlich K.F., Chemical changes during growth and starvation of larval Pleuronectes platessa, Mar. Biol. 24 (1974) 39-48.

[24] Fage L., Le plateau continental et la métamorphose des poissons, Mém. Soc. Biogéogr. 7 (1940) 23-29.

[25] Folkvord A., Hunter J.R., Size-specific vulnerability of northern anchovy, Engraulis mordax, larvae to predation by fishes, Fish. Bull. 84 (1986) 859-869.

[26] Fuiman L.A., What can flatfish ontogenies tell us about pelagic and benthic lifestyles ?, J. Sea. Res. 37 (1997) 257-268.

[27] Fuiman L.A., Higgs D.M., Ontogeny, growth and the recruitment process, in: Chambers R.C., Trippel E.A. (Eds.), Early life history and recruitment in fish population, Chapman \& Hall, London, 1997, pp. 225-245.

[28] Galois R., Lagardere F., Richard P., Changes in biochemical composition and otolith microstructure of larval common sole, Solea solea (L.) under experimental starvation, La Mer 28 (1990) 273-285.

[29] Gibson R.N., Impact of habitat quality and quantity on the recruitment of juvenile flatfishes, Neth. J. Sea. Res. 32 (1994) 191-206.

[30] Gibson R.N., Blaxter J.A.S., De Groot S.J., Developmental changes in the activity rhythms of the plaice (Pleuronectes platessa L.) in: Thorpe J.E. (Eds), The rhythmic activity of fishes, Academic Press, New York, 1978, pp. 169-186.

[31] Hakanson J.L., Nutritional condition and growth rate of anchovy larvae (Engraulis mordax) in the California Current: two contrasting years, Mar. Biol. 115 (1993) 309-316.

[32] Hjort J., Fluctuations in the year classes of important food fishes, J. Cons. perm. int. Explor. Mer. 1 (1926) 5-38.

[33] Hoar W.S., Endocrine organs, in: Brown M.E. (Eds.), The physiology of fishes, 1, 1957 pp. 246-285.

[34] Hovenkamp F., Immigration of larval plaice Pleuronectes platessa in the western Wadden Sea: a question of timing, Neth. J. Sea Res. 27 (1991) 287-296. 
[35] Inui Y., Miwa S., Thyroid hormone induces metamorphosis of flounder larvae, Gen. Comparative Endocrinol. 60 (1985) $450-454$.

[36] Keef K., Able K.W., Patterns of metamorphosis in summer flounder, Paralichthys dentatus, J. Fish. Biol. 42 (1993) 713728.

[37] Koutsikopoulos C., Désaunay Y., Dorel D., Marchand J., The role of coastal areas in the life history of sole (Solea solea (L.)) in the bay of Biscay, Scient. Mar. 53 (1989) 567-575.

[38] Koutsikopoulos C., Fortier L., Gagné J.A., Cross-shelf dispersion of Dover sole eggs and larvae (Solea solea L.) in the Biscay Bay and recruitment to inshore nurseries, J. Plankton. Res. 13 (1991) 923-945.

[39] Lagardère F., Environnement péri-estuarien et biologie des Soleidae dans le golfe de Gascogne (zone sud) à travers l'étude du céteau, Dicologlossa cuneata (Moreau, 1881), thèse dr. Univ. Aix-marseille II, (1982) 303 p.

[40] Lagardère J.P., Feeding ecology and daily food consumption of common sole, Solea vulgaris Quensel, juveniles on the French Atlantic coast, J. Fish Biol. 30 (1987) 91-104.

[41] Lagardère F., Troadec H., Age estimation in common sole Solea solea larvae: validation of daily increments and evaluation of a pattern recognition technique, Mar. Ecol. Prog. Ser. 155 (1997) 223-237.

[42] Lagardère F., Amara R., Joassard L., Vertical distribution and feeding activity of metamorphosing sole, Solea solea (L.), before immigration to the Bay of Vilaine nursery (Northern Bay of Biscay, France), Environ. Biol. Fish. 56 (1999) 213228.

[43] Laurence G.C., Laboratory growth and metabolism of the winter flounder Pseudopleuronectes americanus from hatching through metamorphosis at three temperatures, Mar. Biol. 32 (1977) $223-229$.

[44] Lochmann S.E., Maillet G.L., Frank T.F., Taggart C.T., Lipid class composition as a measure of the nutritional condition in individual larval Atlantic cod (Gadus morhua), Can. J. Fish. Aquat. Sci. 52 (1995) 1294-1306.

[45] Macquart-Moulin C., Castelbon C., Champalbert G., Chikhi D., Le Direach-Boursier L., Patriti G., The role of barosensitivity in the control of migrations of larval and juvenile sole (Solea solea $\mathrm{L}$.): influence of pressure variations on swimming activity and orientation, Rapp. P.-v. Réun. Cons. int. Explor. Mer 191 (1989) 400-408.

[46] Marchand J., The influence of environmental conditions on the settlement, distribution and growth of 0-group sole (Solea solea $(\mathrm{L})$.$) in a macrotidal estuary (Vilaine, France), Neth. J.$ Sea Res. 27 (1991) 307-316.

[47] Marchand J., Métamorphose et passage pelagos/benthos chez la sole (Solea solea): synthèse des données acquises dans le site atelier de la vilaine et perspectives de recherche, Ann. Inst. Océanogr. Paris 68 (1992) (1986) 141-150.

[48] Marchand J., Masson G., Process of estuarine colonization by 0-group sole (Solea solea): hydrological conditions, behaviour, and feeding activity in the Vilaine estuary, Rapp. P.-v. Réun. Cons. int. Explor. Mer. 191 (1989) 287-295.
[49] McCormick M.I., Variability in age and size at settlement of the tropical goatfish Upeneus tragula (Mullidae) in the northern Great Barrier Reef lagoon, Mar. Ecol. Progr. Ser. 103 (1994) 1-15.

[50] McCormick M.I., Molony B.W., Quality of the reef fish Upeneus tragula (Mullidae) at settlement: is size a good indicator of condition ?, Mar. Ecol. Prog. Ser. 98 (1993) 45-54.

[51] Minami T., Tanaka M., Life history cycles in flatfish from the northwestern Pacific, with particular reference to their early life histories, Neth. J. Sea Res. 29 (1992) 35-48.

[52] Myers R.A., Cadigan N.G., Density-dependent juvenile mortality in marine demersal fish, Can. J. Fish. Aquat. Sci. 50 (1993) 1576-1590.

[53] Osse J.W.M., Van den Boogaart J.G.M., Size of flatfish larvae at transformation, functional demands and historical constraints, J. Sea. Res. 37 (1997) 229-240.

[54] Person-Le Ruyet J., Boeuf G., Thyroid hormones changes during ontogenesis in hatchery reared sea bass (Dicentrarchus labrax) and sole (Solea vulgaris) larvae, in: Acts $13^{\text {th }}$ Conference of the European Society for Comparative Physiology and Biochemistry: Research for aquaculture, fundamental and applied aspects, Antibes-Juan les Pins, 6-10 octobre 1991.

[55] Peterman R.M., Bradford M.J., Lo N.C.H., Methot R.D., Contribution of early life stages to interannual variability in recruitment of northern anchovy (Engraulis mordax), Can. J. Fish. Aquat. Sci. 45 (1988) 8-16.

[56] Policansky D., Influence of age, size, and temperature on metamorphosis in the starry flounder, Platichthys stellatus, Can. J. Fish. Aquat. Sci. 39 (1982) 514-517.

[57] Richard P., Bergeron J.P., Boulhic M., Galois R., Person-Le Ruyet J., Effect of starvation on RNA, DNA and protein content of laboratory-reared larvae and juveniles of Solea solea, Mar. Ecol. Progr. Ser. 72 (1991) 69-77.

[58] Rijnsdorp A.D., van Stralen M., van der Veer H.W., Selective tidal transport of North Sea plaice larvae Pleuronectes platessa in coastal nursery areas, Trans. Amer. Fish. Soc. 114 (1985) 461-470.

[59] Rijnsdorp A.D., Van Beek F.A., Flatman S., Millner R.M., Riley J.D., Giret M., De Clerck R., Recruitment of sole stocks, Solea solea (L.) in the northeast Atlantic, Neth. J. Sea Res. 29 (1992) 173-192.

[60] Ryland J.S., Observations on the development of larvae of the plaice (Pleuronectes platessa) in aquaria, J. Cons. Perm. Int. Explor. Mer. 30 (1966) 177-195.

[61] Tanaka M., Kawai S., Seika T., Burke J.S., Development of the digestive organ system in Japanese flounder in relation to metamorphosis and settlement, Mar. Freshwater Behav. Physiol. 28 (1996) 19-31.

[62] Thorisson K., Is metamorphosis a critical stage in the early life of marine fishes ?, ICES CM L: 37, 1992.

[63] Van der Veer H.W., Immigration, settlement and density-dependent mortality of a larval and early post-larval 0-group plaice (Pleuronectes platessa) population in the western Wadden Sea, Mar. Ecol. Progr. Ser. 29 (1986) 223-236. 
[64] Van der Veer H.W., Bergman M.J.M., Predation by crustaceans on a newly settled 0-group plaice Pleuronectes platessa population in the Western Wadden Sea, Mar. Ecol. Progr. Ser. 35 (1987) 203-215.

[65] Victor B.C., Delayed metamorphosis with reduced larval growth in a coral reef fish (Thalassoma bifasciatum), Can. J. Fish. Aquat. Sci. 43 (1986) 1208-1213.

[66] Wennhage H., Gibson R.N., Influence of food supply and a potential predator (Crangon crangon) on settling behaviour of plaice (Pleuronectes platessa), J. Sea. Res. 39 (1998) 103-112.
[67] Witting D.A., Able K.W., Effects of body size on probability of predation for juvenile summer flounder, Paralichthys dentatus and winter flounder, Pleuronectes americanus, based on laboratory experiments, Fish. Bull. 91 (1993) 577581.

[68] Youson J.H. 1988. First metamorphosis, in: Hoar W.S., Randall D.J. (Eds.), Fish Physiol. 11B, Academic Press, NY, 1988, 135-196.

[69] Zijlstra J.J., Witte J.J.J., On the recruitment of 0-group plaice in the North Sea, Neth. J. Zool. 35 (1985) 360-376. 